\title{
BMJ Open A rapid systematic review of measures to protect older people in long-term care facilities from COVID-19
}

\author{
Kate Frazer (D) , ${ }^{1}$ Lachlan Mitchell (D) , ${ }^{2,3}$ Diarmuid Stokes, ${ }^{4}$ Ella Lacey, ${ }^{5}$ \\ Eibhlin Crowley, ${ }^{6}$ Cecily C Kelleher ${ }^{2,3}$
}

To cite: Frazer K, Mitchell L, Stokes $\mathrm{D}$, et al. A rapid systematic review of measures to protect older people in long-term care facilities from COVID-19. BMJ Open 2021;11:e047012. doi:10.1136/ bmjopen-2020-047012

- Prepublication history and additional supplemental material for this paper are available online. To view these files, please visit the journal online (http://dx.doi.org/10.1136/ bmjopen-2020-047012).

KF and LM contributed equally.

Received 17 November 2020 Accepted 29 August 2021

Check for updates

(C) Author(s) (or their employer(s)) 2021. Re-use permitted under CC BY-NC. No commercial re-use. See rights and permissions. Published by BMJ.

${ }^{1}$ School of Nursing, Midwifery and Health Systems, University College Dublin, Dublin, Ireland ${ }^{2}$ National Nutrition Surveillance Centre, University College Dublin, Dublin, Ireland

${ }^{3}$ School of Public Health, Physiotherapy and Sport Science, University College Dublin, Dublin, Ireland ${ }^{4}$ Health Sciences Library, University College Dublin, Dublin, Ireland

${ }^{5}$ School of Medicine, University College Dublin, Dublin, Ireland ${ }^{6}$ Office for Health Affairs, College of Health and Agricultural Science, University College Dublin, Dublin, Ireland

Correspondence to Dr Lachlan Mitchell; lachlan.mitchell@ucd.ie

\section{ABSTRACT}

Objectives The global COVID-19 pandemic produced large-scale health and economic complications. Older people and those with comorbidities are particularly vulnerable to this virus, with nursing homes and long term care facilities (LTCF) experiencing significant morbidity and mortality associated with COVID-19 outbreaks. The aim of this rapid systematic review was to investigate measures implemented in LTCF to reduce transmission of COVID-19 and their effect on morbidity and mortality of residents, staff and visitors.

Setting Long-term care facilities.

Participants Residents, staff and visitors of facilities. Primary and secondary outcome measures Databases (PubMed, EMBASE, CINAHL, Cochrane Databases and repositories and MedRXiv prepublished database) were systematically searched from inception to 27 July 2020 to identify studies reporting assessment of interventions to reduce transmission of COVID-19 in nursing homes among residents, staff or visitors. Outcome measures include facility characteristics, morbidity data, case fatalities and transmission rates. Due to study quality and heterogeneity, no meta-analysis was conducted.

Results The search yielded 1414 articles, with 38 studies included. Reported interventions include mass testing, use of personal protective equipment, symptom screening, visitor restrictions, hand hygiene and droplet/ contact precautions, and resident cohorting. Prevalence rates ranged from $1.2 \%$ to $85.4 \%$ in residents and $0.6 \%$ to $62.6 \%$ in staff. Mortality rates ranged from $5.3 \%$ to $55.3 \%$ in residents.

Conclusions Novel evidence in this review details the impact of facility size, availability of staff and practices of operating between multiple facilities, and for-profit status of facilities as factors contributing to the size and number of COVID-19 outbreaks. No causative relationships can be determined; however, this review provides evidence of interventions that reduce transmission of COVID-19 in LTCF.

PROSPERO registration number CRD42020191569.

\section{INTRODUCTION}

SARS-CoV-2 is a novel virus, first identified in China in 2019, resulting in the current global pandemic in 2020. ${ }^{1}$ The ensuing disease associated with infection from SARS-CoV-2, termed COVID-19, has produced large-scale

\section{Strengths and limitations of this study}

- Evidence from 38 studies identifies the measures taken to reduce transmission of COVID-19 in longterm care facilities.

- No limitations were placed on study type, and all languages were eligible for inclusion.

- Study quality was formally examined using the Mixed Methods Assessment Tool.

Due to the heterogeneity of included studies, metaanalysis was not able to be performed.

public health and worldwide economic effects. $^{2}$

The virus spreads between people through close contact and droplet transmission (coughs and sneezes). While most infected people will experience mild influenza-like symptoms, others may become seriously ill and die. ${ }^{3}$ At-risk groups include older people and those with underlying medical conditions, while men appear to have more susceptibility than women. Symptom severity varies; several individuals remain asymptomatic. Others experience fever, cough, sore throat, general weakness and fatigue, while more severe respiratory illnesses and infections may result, which can be fatal. ${ }^{4}$ Deterioration in clinical presentations can occur rapidly, leading to poorer health outcomes. Anosmia and ageusia are reported in evidence from South Korea, China and Italy in patients with confirmed SARS-CoV-2 infection, in some cases in the absence of other symptoms. ${ }^{6}$

The WHO declared the COVID-19 outbreak constituted a Public Health Emergency of International Concern on 30 January $2020 .^{5}$ Two primary goals of action were (1) to accelerate innovative research to help contain the spread and facilitate care for all affected and (2) to support research priorities globally the learning from the pandemic response for preparedness. Globally, up to 25 March 2021, there are 123636852 cases 
of COVID-19 (following the applied case definitions and testing strategies in the affected countries) including 2 721891 deaths. ${ }^{7}$ Within Europe, over 25220376 cases are reported, with 592929 deaths. ${ }^{7}$

Given the infection and mortality figures noted, preventing and limiting transmission of the SARS-CoV-2 virus is advocated. International and national evidence mandates physical distancing, regular hand hygiene and cough etiquette, and limiting touching eyes, nose or mouth; in addition to regular cleaning of surfaces. ${ }^{8}$

As noted, older people are an at-risk group for COVID19 , and throughout the pandemic, the impact on this population has resulted in increased mortality, specifically those living in long term care facilities (LTCF) where a high proportion of outbreaks with increased rates of morbidity and case fatality in residents are recorded..$^{9}$ In several European Union/European Economic Area countries, LTCF deaths among residents, associated with COVID-19, account for $37 \%-66 \%$ of all COVID-19-related fatalities. ${ }^{9}$ The specific rationale for their increased susceptibility is less clear. Comorbidities including cardiovascular disease and diabetes may increase the chances of fatal disease, but they alone do not explain why age is an independent risk factor. ${ }^{10}$ Molecular, biological and immunological changes inform emergent viable hypotheses. ${ }^{10}$ The United Nations (UN) (2020) acknowledge that COVID-19 exposes the inequalities in society and the failures expressed in the 2030 Agenda for Sustainable Development. The UN report the disproportionate fatality rates in those aged over 80 years as five times the global average ${ }^{11}$ and suggest a need for a more inclusive, equitable and age-friendly society, anchored in human rights (p16). ${ }^{12}$

The aim of this rapid review of the literature was to assess the extent to which measures implemented in LTCF reduced transmission of COVID-19 (SARS-CoV-2) among residents, staff and visitors, and the effect of these measures on morbidity and mortality outcomes.

\section{METHODS}

The protocol is registered on PROSPERO ${ }^{13}$ and reporting follows Preferred Reporting Items for Systematic Reviews and Meta-Analyses guidelines. ${ }^{14}$ Ethical approval was not required for this systematic review.

\section{Search strategy}

Search strategies comprised search terms both for keywords and controlled-vocabulary search terms MESH and EMTREE (see online supplemental table 1 for full search terms). EMBASE (via OVID), PubMed (via OVID), Cumulative Index to Nursing and Allied Health Literature (CINAHL), Cochrane Database and Repository and MedRXiv prepublished databases were searched. No time limits were imposed, and databases were searched up to 27 July 2020. Reference lists of included evidence were checked for further articles.

\section{Eligibility criteria}

All study designs (experimental, observational and qualitative) are included, and no exclusions are placed on language. Included studies report an assessment of measures to reduce transmission of COVID-19 (including SARS or Middle Eastern Resipratory Virus (MERS)) in residents, employees or visitors of LTCF. To provide as comprehensive a review of the evidence we included any intervention implemented to reduce the transmission of COVID-19 in LTCF, including facility measures, social distancing, use of personal protective equipment (PPE) and hand hygiene.

A broad definition of LTCF was adopted for this review noting European Centre for Disease Prevention and Control (ECDC) guidance ${ }^{8}$ including institutions such as nursing homes, skilled nursing facilities, retirement homes, assisted-living facilities, residential care homes or other facilities providing care in a congregated setting for older aged adults.

\section{Primary outcome measures}

Primary outcome measures are morbidity data, case fatality rates and reductions in reported transmission rates.

\section{Secondary outcomes}

Secondary outcomes reported are facility characteristics associated with COVID-19 transmission.

\section{Selection of studies and data extraction}

Two authors developed search strings (DS and KF); all database searches were completed by one author (DS) (online supplemental table 1). Following de-duplication, references were uploaded into Covidence management platform (LM), and two authors independently screened all titles and abstracts (LM and KF). Full texts of all potentially eligible studies were independently reviewed by two authors (LM and KF). Disagreements were resolved by discussion with a third author (CCK). Data from included studies were independently extracted in duplicate (LM and KF). A data extraction form was developed and modified from documents used previously by authors (KF and CCK). Extracted data included study characteristics (title, lead author, year of publication, country, study setting, study design), description of the intervention, number and characteristics of participants, outcomes, duration of follow-up, sources of funding, peer review status. Study design (required for review of quality) was independently assessed by two authors ( $\mathrm{LM}$ and $\mathrm{KF}$ ), with disagreements resolved by a third author (CCK).

\section{Assessment of quality}

Two review authors (LM and EL) independently assessed the quality of included studies using Mixed Methods Assessment Tool (MMAT) ${ }^{15}$ with disagreements resolved by a third author (KF) and discussed with the lead author (CCK) (online supplemental table 2). The MMAT is used widely and considered a valid indicator of methodological quality using instruments for non-randomised and descriptive studies. 


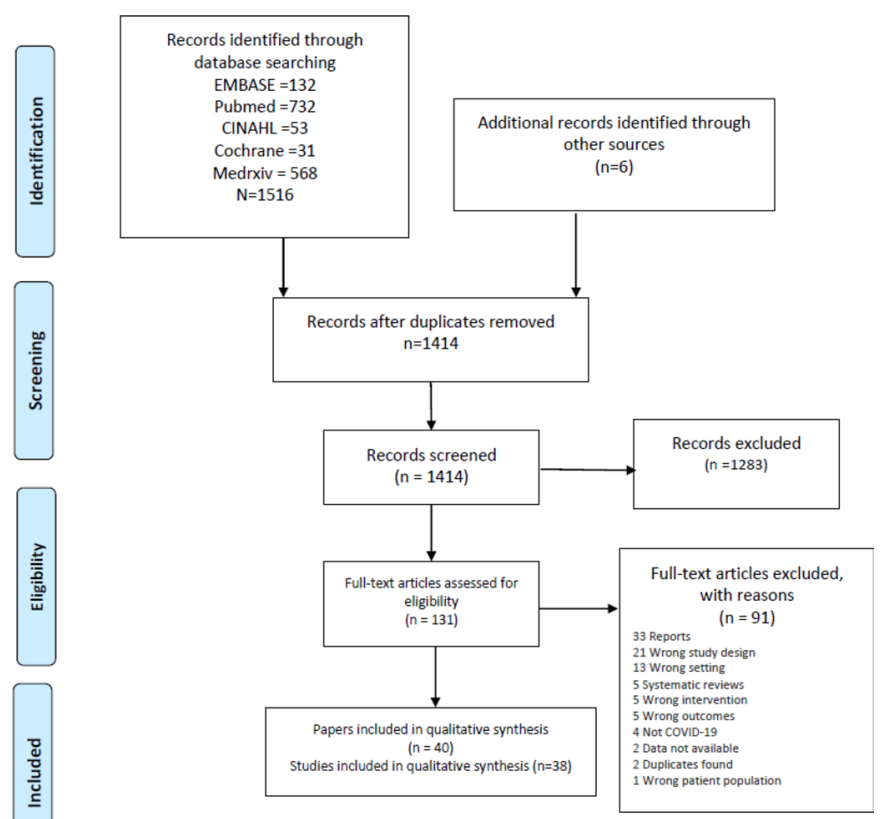

Figure 1 Preferred Reporting Items for Systematic Reviews and Meta-Analyses flowchart.

\section{Data synthesis}

Meta-analysis was not possible due to heterogeneity in study designs, participants, outcomes and nature of the interventions and no attempt was made to transform statistical data. The Synthesis without meta-analysis (SWiM) criteria $^{16}$ guide a narrative summary, with data presented in tabular format and subgroup reporting of population groups.

\section{Patient and public involvement}

No patients were involved in this study.

\section{RESULTS}

We identified 1414 articles and 131 full-text articles were selected for review. After an evaluation against our inclusion criteria, 38 studies (40 papers) are included in this systematic review (figure 1).

\section{Study characteristics}

Geographically we report evidence from 11 countries; the majority (20 studies) are from $\mathrm{USA}^{17-36}$ and $\mathrm{UK}^{37-41}$ We report evidence from Canada, ${ }^{42-44}$ France, ${ }^{45}{ }^{46}$ Hong Kong, ${ }^{47}{ }^{48}$ Belgium, ${ }^{49}$ Germany, ${ }^{50}$ Ireland, ${ }^{51}$ Japan, ${ }^{52}$ Korea $^{53}$ and Spain $^{54}$ (table 1).

\section{Infection control measures}

Twenty studies report the nature of LTCFs related to outbreaks and transmission of COVID-19 infec-

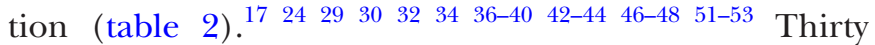
studies (table $3^{18-3033-3538-4446-5154}$ ); report evidence of measures to reduce transmission of COVID-19 in longterm residential care facilities for residents, 25 studies (table $4^{18-232527-313335394043-495154}$ ); report evidence for employee outcomes, and two studies report evidence for visitors (table 5). ${ }^{29} 48$

A variety of infection control measures are described (tables 1 and 3-5) including: mass testing/point-prevalence testing (22 studies ${ }^{18}$ 20-23 26-31 33-35 $3940454649-5154$ ), use of PPE (10 studies ${ }^{18192126293033464850}$ ), screening of residents, staff or visitors for symptoms (8 studies $^{19-21} 2426283033$ ), restrictions on visitor entry (10 studies ${ }^{19-2126283033465054}$ ), hand hygiene and contact and droplet precautions (6 studies $^{202426334647}$ ) and cohorting/isolation of residents (11 studies 2021232629303334464850 ). Thirteen studies examined characteristics of LTCF and their association with

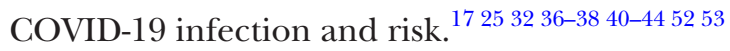

\section{Morbidity and mortality}

Morbidity and mortality results from included studies are presented for residents (table 3), staff (table 4) and visitors (table 5). Prevalence of COVID-19 infection was reported in 29 studies, including prevalence in residents (27 studies $^{18-30 ~ 33-353940424446-5154}$ ) and staff (22 studies ${ }^{1820-232527-313335394045-495154}$ ), with two studies reporting absolute case numbers in visitors. ${ }^{29} 48$ Prevalence rates ranged from $3.8 \%$ in a sample of 2074 LTCF $^{49}$ and $1.2 \%$ in the third point-prevalence survey at a single facility ${ }^{21}$ to $85.4 \%$ in a single facility that implemented a telemedicine service to limit transmission. ${ }^{25}$ Staff prevalence ranged from $0.6 \%$ in a point-prevalence survey in a single facility $^{21}$ to $62.6 \%$ in a group of nine LTCF. $^{22}$ One study reported 16 COVID-19 positive visitor cases, ${ }^{29}$ while a study that examined SARS infection following an outbreak in a Hong Kong facility reported three positive visitor cases. $^{48}$

The symptom status (symptomatic/presymptomatic/ asymptomatic, typical/atypical symptoms) of participants was reported in 16 studies, with resident and staff symptom status reported in 15 18-20222326-2830333446495154

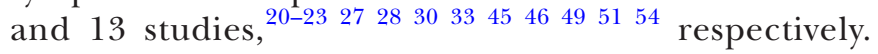
No studies reported symptom status of visitors. The proportion of COVID-19 positive residents presenting with symptoms ranged from $26.3 \%^{2027}$ to $59.8 \%$ (a sample of both residents and healthcare workers).$^{28}$ Asymptomatic cases in residents were reported in 13 studies, ${ }^{18} 20222326-28303346495154$ with proportions of COVID-19 positive residents presenting with no symptoms varying from $2.4 \%{ }^{46}$ to $75.3 \%{ }^{49}$ Among COVID-19 positive staff, the proportion of symptomatic cases ranged from $6.4 \%^{27}$ to $100 \%,{ }^{33}$ and asymptomatic cases ranged from $23.6 \%{ }^{51}$ to $100 \% .{ }^{21} 23$

Mortality results were reported in 22 studies, including information on mortality of residents (22 studies ${ }^{18-20} \quad 23-25 \quad 28-30 \quad 34 \quad 35 \quad 38-44 \quad 46 \quad 48 \quad 50 \quad 51$ ), staff (4 studies $^{29354648}$ ) and visitors (2 studies ${ }^{29} 48$ ). Mortality rates in COVID-19 positive residents ranged from $5.3 \%{ }^{20}$ to $55.3 \% .^{39}$ One study reported a $66.7 \%$ death rate in residents who tested positive for the SARS virus. ${ }^{48}$ A study examining the mortality risk in 


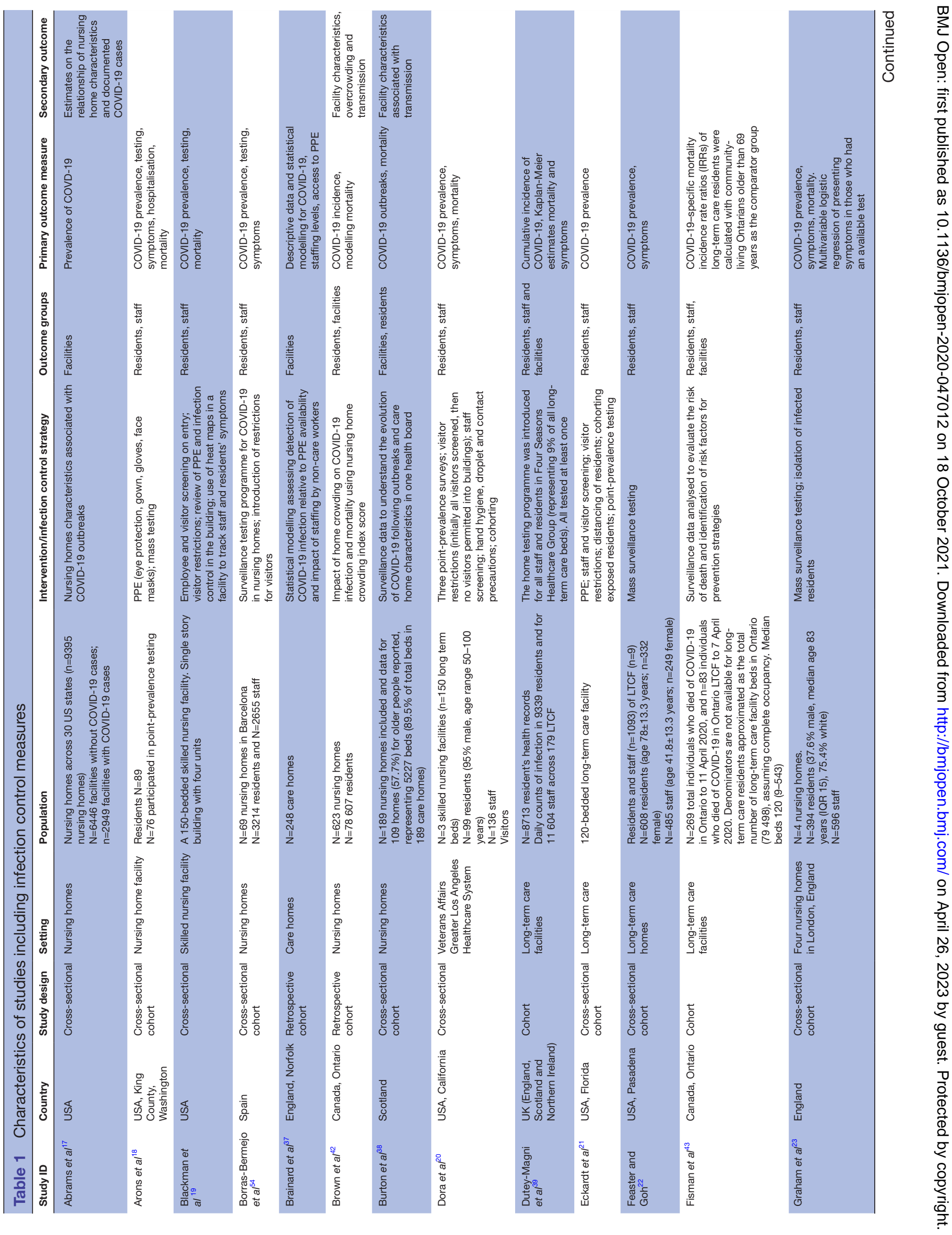




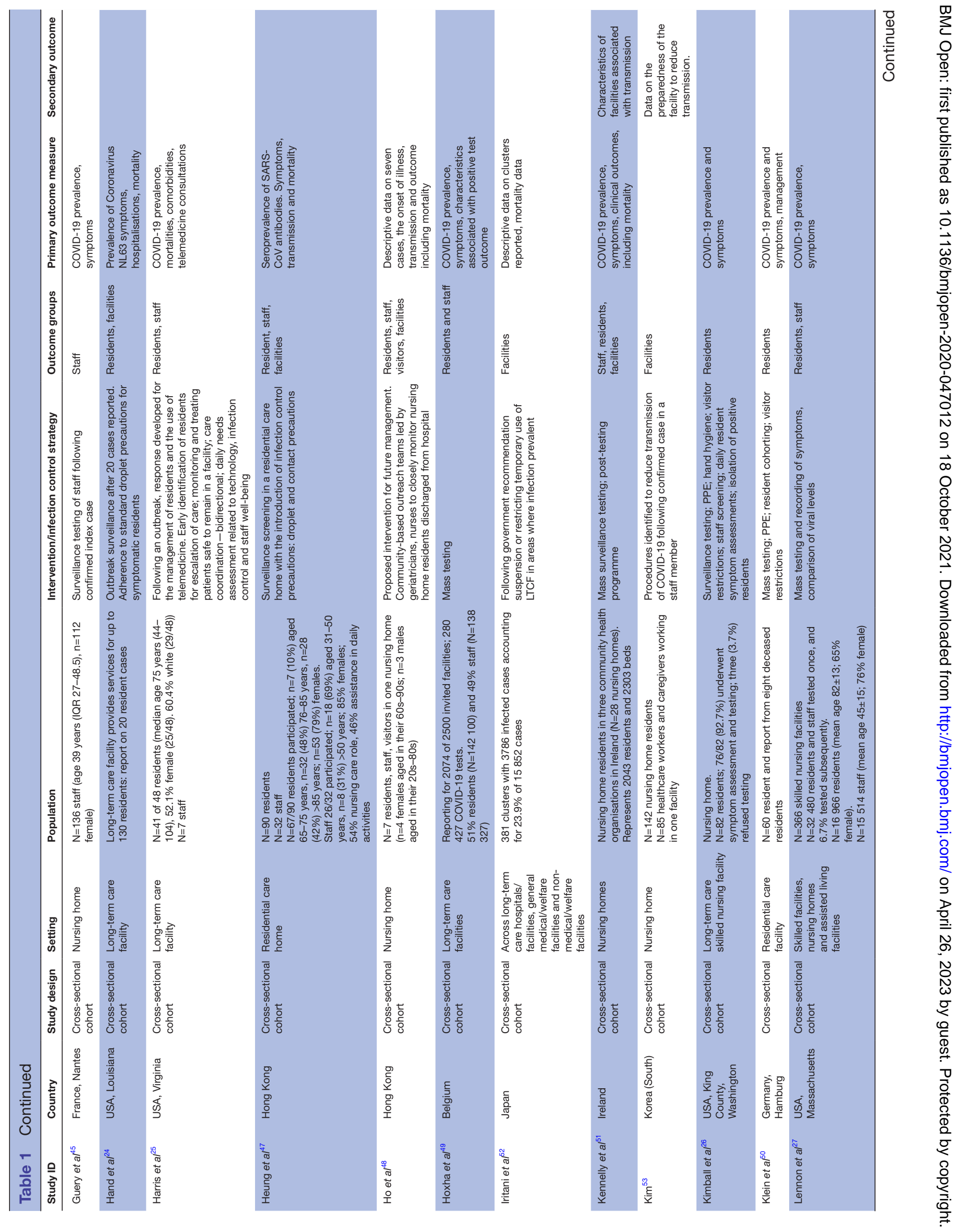




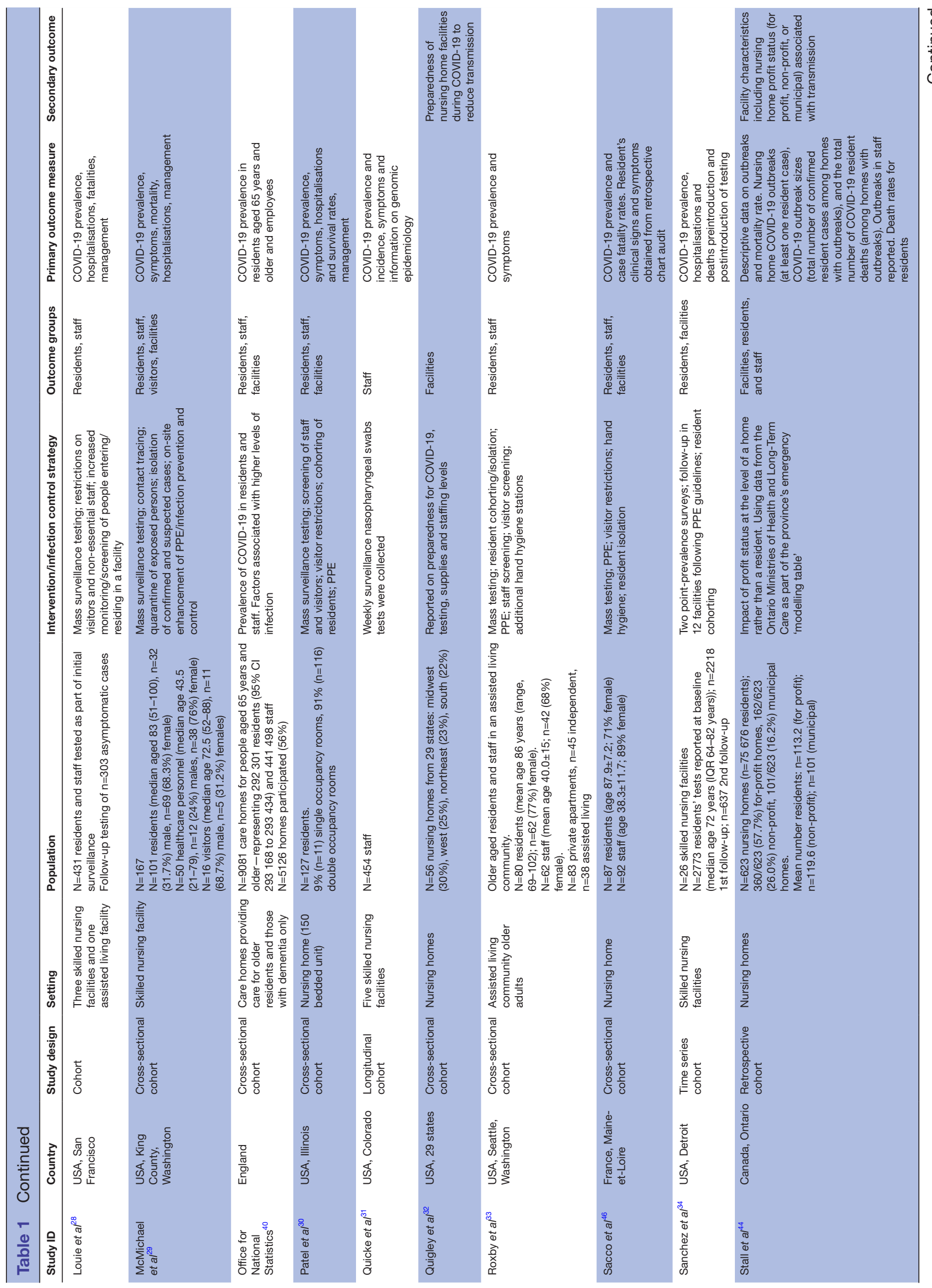




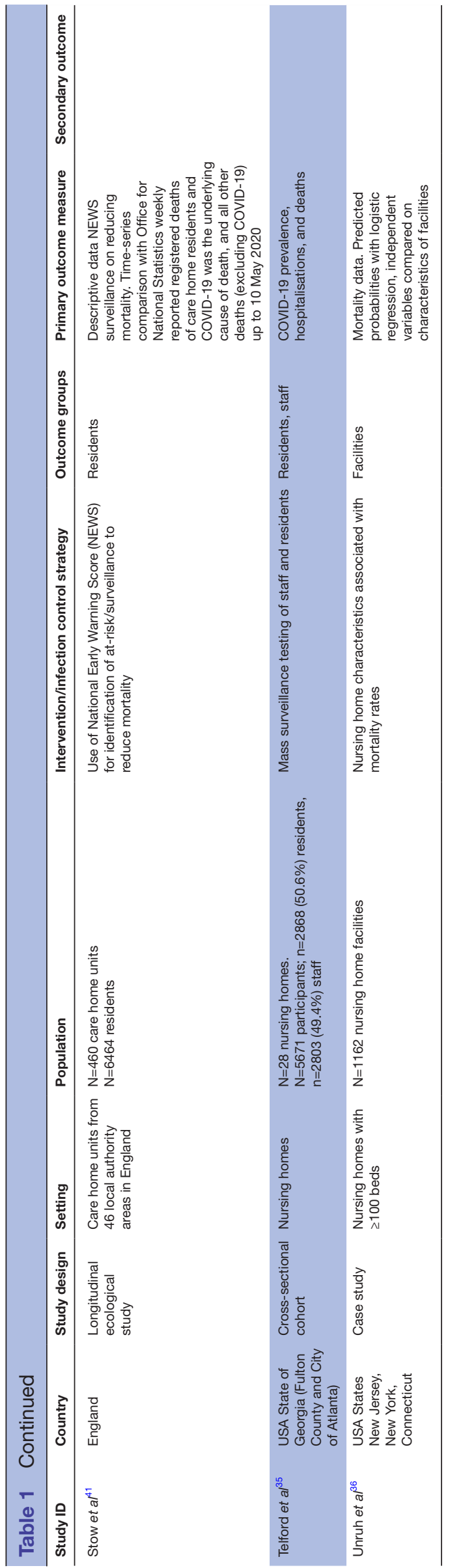

Ontario LTCF reported a death rate of $0.1 \%$ across all residents. ${ }^{43}$ Across the three studies which presented mortality results in COVID-19 positive staff, mortality rates were $0 \% .{ }^{29} 3546$ One study presenting mortality rates in a nursing home following a SARS outbreak reported one death of a member of staff. ${ }^{48}$ Mortality rates reported in visitors in two studies was $0 \%$ and $6.2 \%,{ }^{29}$ respectively.

\section{Characteristics of LTCFs on COVID-19 transmission}

Numerous facility-specific characteristics were linked with risk of COVID-19 cases (table 2). These include size of LTCF $^{17} 383952$; staffing levels and/or use of agency care staff $^{29} 323739404451$; part of larger chain of organisations and/or for profit status ${ }^{172} 36434451$; and related staffing, crowding, or availability of single rooms. ${ }^{24} 3040424446-48$

\section{Quality review}

The quality ratings of included studies are presented in online supplemental table 2. Overall quality of evidence in this review is considered low based on MMAT assessment criteria.

\section{DISCUSSION}

Evidence in this review indicates the impact of COVID-19 on LTCF, demonstrating the vulnerability of this setting in 11 countries. A novel outcome highlights the characteristics of LTCF associated with COVID-19 outbreaks, in addition to reporting the prevalence rates of COVID-19 and associated mortality and morbidity for residents, staff and visitors. A variety of measures were implemented in LTCF, of which many were instigated locally by facility managers, and others through agile public health policy. Due to the rapid nature of introducing public health measures though, the evidence base does not facilitate an evaluation of the effects of these measures individually. Mass testing of residents with or without staff testing was the primary measure used to reduce transmission of COVID-19. This provides objective evidence of infection rates in facilities, and enables application of subsequent measures, including isolation of residents who are infected with re-designation of specific staff to care for them. Repeated point-prevalence testing allows facilities to grasp the spread of the virus along with the impact of their mitigation strategies.

Further measures implemented in facilities echoed public health recommendations to the broader community to limit the spread of the virus. These included guidance on hand hygiene, contact and droplet precautions, and restricting staff, including agency workers, to working in only one facility. ${ }^{55}$ Restricting visitor access to facilities was implemented generally to reduce the likelihood of introducing COVID-19 into LTCF, assessing body temperature and symptom screening of staff and visitors on entry.

The prevalence of COVID-19 infection varied throughout included studies, with no distinct pattern emerging between prevention strategies and infection 


Table 2 COVID-19 outcomes related to the nature of long-term care facilities
\begin{tabular}{lll} 
Study & Facilities & Outcomes \\
\hline Abrams et $a l^{17}$ & Facilities & Average number of cases was 19.8 (range 1-256). New Jersey (88.6\%, OR 7.16) and Massachusetts (78.0\%, OR 4.36) had
\end{tabular}
a higher number of affected facilities.

Probability of having a COVID-19 case:

Facility size (relative to small): large $\mathrm{OR}=6.52$; medium $\mathrm{OR}=2.63$.

Location (relative to rural): urban $\mathrm{OR}=3.22$.

$\%$ African American residents (relative to low \%): greater \% OR=2.05.

Nursing home chain status (relative to non-chain status): chain status $\mathrm{OR}=0.89$.

States were significantly related to the probability of having COVID-19 case.

Outbreak size associations:

Facility size (relative to small facility size): large $=-15.88$; medium $=-10.8$ (percentage point change).

For-profit status (relative to non-profit status) $=1.88$.

State.

Medicaid dependency, ownership, five-star rating and prior infection violation were not significantly related to COVID-19 cases.

Brainard et $a l^{37} \quad$ Facilities $\quad$ Risk of infection:

Facility employee numbers (relative to $<10$ workers): $11-20$ non-care workers $\mathrm{HR}=6.502$ (95\% Cl 2.614 to 16.17 ); $21-30$ non-care workers $\mathrm{HR}=9.870$ ( $95 \% \mathrm{Cl} 3.224$ to 30.22$)$; >30 non-care workers $\mathrm{HR}=18.927$ (95\% Cl 2.358 to 151.90$)$.

Predictors of spread and increase in cases per unit after 5 April risk increased $1.0347(95 \% \mathrm{Cl} 1.02$ to 1.05$) \mathrm{p}<0.001$, reduced availability of PPE for eye protection increased risk 1.6571 (95\% Cl 1.29 to 2.13 ) $p<0.001$, PPE for facemasks $1.2602(95 \% \mathrm{Cl} 1.09$ to 1.46$) \mathrm{p}=0.002$, count of care workers employed $1.0379(95 \% \mathrm{Cl} 1.02$ to 1.05$) \mathrm{p}<0.001$ count of nurses employed (in bands of $0-10,11-20,21-30$ and $31+) 1.1814$ (95\% Cl 1.13 to 1.24 ) $\mathrm{p}<0.001$.

\begin{tabular}{|c|c|c|}
\hline Brown et $a^{42}$ & Facilities & $\begin{array}{l}\text { Incidence in high crowding index homes was } 9.7 \% \text { vs } 4.5 \% \text { in low crowding index homes ( } p<0.001) \text {, while COVID- } 19 \\
\text { mortality was } 2.7 \% \text { vs } 1.3 \% \text {. Likelihood of COVID- } 19 \text { introduction did not differ }(31.3 \% \text { vs } 30.2 \%, p=0.79) \text {. After adjustment } \\
\text { for a regional nursing home, and resident covariates, the crowding index remained associated with increased risk of } \\
\text { infection (RR=1.72, } 95 \% \mathrm{Cl} 1.11 \text { to } 2.65 \text { ) and mortality (RR=1.72, } 95 \% \mathrm{Cl} 1.03 \text { to } 2.86 \text { ). Simulations suggested that } \\
\text { converting all } 4 \text {-bed rooms to } 2 \text {-bed rooms would have averted } 988(18.9 \%) \text { infections of COVID-19 and } 271 \text { (18.7\%) } \\
\text { deaths. }\end{array}$ \\
\hline Burton et $a^{38}$ & Facilities & $\begin{array}{l}\text { Significant associations between the presence of an outbreak and number of beds (OR per 20-bed increase } 3.50 \text { ), a history } \\
\text { of multiple outbreaks (OR } 3.76 \text { ) and regulatory risk assessment score (OR high-risk vs low } 2.19 \text { ). However, in the adjusted } \\
\text { analysis, only number of beds (OR per 20-bed increase } 3.50,95 \% \mathrm{Cl} 2.06 \text { to } 5.94 \text { per } 20 \text {-bed increase). }\end{array}$ \\
\hline Fisman et $a l^{43}$ & Facilities & COVID-19 cases higher in for-profit operators $165 / 361$ (45.7\%) compared with charitable 18/57 (31.6\%). \\
\hline Hand et $\left.a\right|^{24}$ & Facilities & $\begin{array}{l}\text { Residents noted to share rooms, walk throughout the facility and spent time in shared areas (eg, gym, dining rooms and } \\
\text { recreational rooms). Because all case-patients had visited the gym at the facility for recreation or physical therapy before } \\
\text { becoming ill, environmental cleaning of this area was performed. }\end{array}$ \\
\hline Ho et $a l^{48}$ & Facilities & $\begin{array}{l}3 \text { residents positive for SARS. } 1 \text { employee positive for SARS. } 3 \text { visitors positive for SARS. The index case was a single } \\
\text { resident who was infected during a hospital stay, returned to the LTCF, and the virus spread to another six people. } \\
\text { Transmission of the virus occurred due to lack of isolation rooms in nursing homes, lack of restricted movement of other } \\
\text { patients and relatives, lack of infection control precautions, lack of knowledge among staff. }\end{array}$ \\
\hline Iritani et al ${ }^{52}$ & Facilities & $\begin{array}{l}\text { Larger cluster sizes in long term care hospitals/facilities were significantly positively associated with higher morbidity } \\
(\rho=0.336, p=0.006) \text { and higher mortality }(\rho=0.317, p=0.009) \text {. } \\
\text { Multivariate logistic regression showed larger cluster size (OR=1.077, } 95 \% \mathrm{Cl} 1.017 \text { to } 1.145) \text { and larger cluster number } \\
(\mathrm{OR}=2.019,95 \% \mathrm{Cl} 1.197 \text { to } 3.404 \text { ) associated with mortality. }\end{array}$ \\
\hline
\end{tabular}


Table 2 Continued

\begin{tabular}{|c|c|c|}
\hline Study & Facilities & Outcomes \\
\hline McMichael et $a l^{29}$ & Facilities & $\begin{array}{l}28 \text { February } 2020 \text {, four cases COVID-19 identified in county. One person identified as index case from facility A. Staff roles } \\
\text { for confirmed cases reported: therapists, nurses, nurse assistants, health information manager, physician and case manage } \\
\text { Paper reports that } 30 \text { facilities in county had confirmed cases and provides detail on the first } 9 \text { (facilities A to I). } \\
\text { Facility A shared staff with another facility and two resident transfers from facility A. Surveillance reported inadequate PPE, } \\
\text { training, infection control practices, lack of documentation signs and symptoms, working in unfamiliar facilities or sharing } \\
\text { staff. On } 10 \text { March } 2020 \text {, the governor of Washington implemented mandatory screening of healthcare workers and visitor } \\
\text { restrictions for all licensed nursing homes and assisted living facilities including screening, testing, policies around visiting, } \\
\text { excluding symptomatic staff, close monitoring of residents, testing, training and PPE. Monitoring of staff absences. }\end{array}$ \\
\hline $\begin{array}{l}\text { Office for National } \\
\text { Statistics }^{40}\end{array}$ & Facilities & $\begin{array}{l}\text { For each additional member of infected staff working at the care home, the odds of resident infection increase by } 11 \% \text {, } \\
\text { that is, OR=1.11 ( } 95 \% \mathrm{Cl} 1.1 \text { to } 1.11) \text {. Care homes using bank or agency nurses or carers most or every day more likely to } \\
\text { have cases in residents (OR=1.58, } 95 \% \mathrm{Cl} 1.5 \text { to } 1.65) \text { compared with those who never use bank or agency staff. Residents } \\
\text { in care homes outside of London had a lower chance of infection, except West Midlands }(\mathrm{OR}=1.09,95 \% \mathrm{Cl} 1.0 \text { to } 1.17) \text {. } \\
\text { Homes where staff receive sick pay are less likely to have resident cases (OR=0.82 to } 0.93,95 \% \mathrm{Cl} 7 \% \text { to } 18 \%) \text {, compared } \\
\text { with homes where no sick leave. For each additional infected resident at a home, the odds of staff infection increase by } \\
4 \% \mathrm{OR}=1.04 \text { ( } 95 \% \mathrm{Cl} 4 \% \text { to } 4 \%) \text {. Care homes using bank or agency staff most or every day OR=1.88 }(95 \% \mathrm{Cl} 1.77 \text { to } 2.0) \\
\text { compared with homes not using. Homes where staff regularly work elsewhere (most or every day) increase odds (OR=2.4, } \\
95 \% \mathrm{Cl} 1.92 \text { to } 3.0) \text { compared with homes who never work elsewhere. Staff at homes outside London had higher odds of } \\
\text { COVID-19 infection. }\end{array}$ \\
\hline
\end{tabular}

\begin{tabular}{|c|c|c|}
\hline Patel et $a l^{30}$ & Facilities & $\begin{array}{l}\text { First resident unwell } 9 \text { March, female aged in her } 60 \text { s with cough and fever. Hospitalised } 11 \text { March and tested positive } \\
\text { COVID-19 } 13 \text { March. } 14 \text { residents who were positive developed symptoms over } 30 \text {-day follow-up. } 21 \%(n=7) \text { confirmed } \\
\text { cases lived in single occupancy rooms. } 55 \%(n=18) \text { were in a double room with another confirmed case, and } 24 \%(n=8) \\
\text { were in a double room with a resident who was negative } 15 \text { March. Screening visitors and staff for symptoms, restricting } \\
\text { visiting hours from } 6 \text { March. No visitor access from } 12 \text { March. Universal masking of all staff and residents from } 14 \text { March. } \\
15-19 \text { March on-site team implemented assessment of symptoms, resident cohorting. Staff testing positive isolated and } \\
\text { return } 7 \text { days or after } 72 \text { hours of symptoms resolving. Education and training to staff in facility A infection control, PPE, vit } \\
\text { signs. }\end{array}$ \\
\hline Quigley et $a l^{32}$ & Facilities & $\begin{array}{l}\text { For-profit=67.86\%, non-profit=26.79\% and government-owned=5.36\%. } 37.5 \% \text { were part of a chain. } 54 \% \text { have COVID-19 } \\
\text { plans. All had staff training for COVID-19 and } 100 \% \text { processes to restrict/ limit visitors. } 29 \% \text { conducted COVID- } 19 \\
\text { simulation training. Communication with local Public Health }-96 \% \text { and } 68 \% \text { linked to local hospital referral. } 66 \% \text { reported } \\
\text { access to COVID-19 tests - available for all residents and } 53 \% \text { of staff. } 72 \% \text { reported inadequate PPE supplies. } 83 \% \\
\text { expected staff shortages. Solutions for staff included staff volunteer for more shifts (55\%), non-clinical staff used (45\%). } \\
19 \% \text { reported they would use agency staff. }\end{array}$ \\
\hline
\end{tabular}

Sacco et al ${ }^{46} \quad$ Facilities Restrictions on residents from 16 March-social distancing, remain in single rooms, no communal dining or group activities.
No visitors since 10 March, individual walks outside only in the presence of one staff member. Mail and packages stored 24 hours before being delivered to residents. Enhanced hygiene and cleaning. Staff had permanent face masks and additional hand hygiene.

Sanchez et $a^{34} \quad$ Facilities Of the 12 facilities in the final survey, 8 had implemented cohorting in a dedicated COVID-19 unit before first follow-up. 4 remaining initiating cohorting after receiving results. 4 facilities did not assign dedicated personnel to care for residents with COVID-19 due to staff shortages. Final survey census 80 residents (range 36-147). 373 of 1063 (35\%) had received positive results first follow-up.

\begin{tabular}{|c|c|c|}
\hline Stall et $\left.a\right|^{44}$ & Facilities & 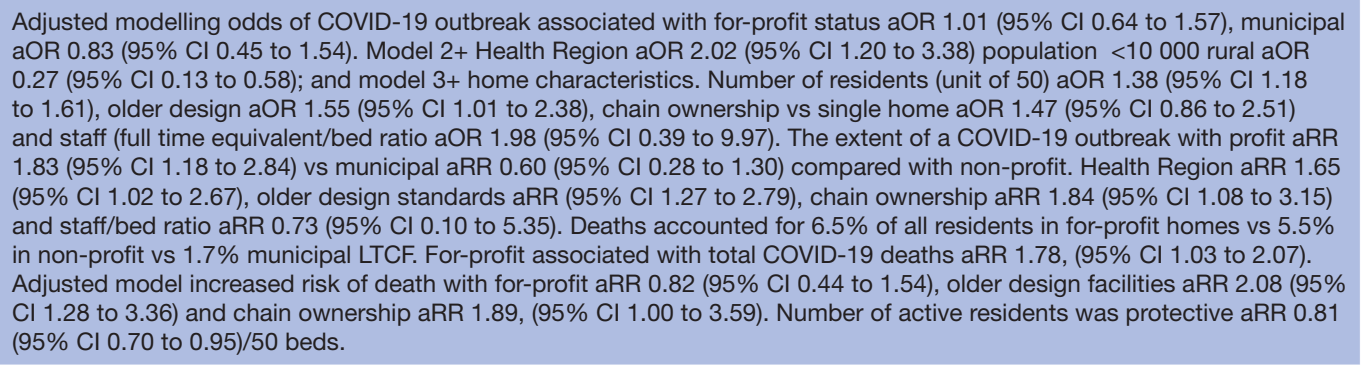 \\
\hline Unruh et $a l^{36}$ & Facilities & $\begin{array}{l}184 \text { nursing homes }(15.8 \%) \text { had } 6 \text { or more COVID-19 deaths. Deaths associated with Medicaid patients (quintile } 5: 8.6 \mathrm{PP} \\
\text { greater probability vs quintile } 1) \text {. Patients with higher } \mathrm{ADL} \text { scores }(2.6(95 \% \mathrm{Cl} 1.4 \text { to } 3.8) \mathrm{PP}, \mathrm{p}<0.001) \text {, more total beds } \\
\text { (0.1 (95\% Cl } 0.0 \text { to } 0.1) \mathrm{PP}, \mathrm{p}<0.001) \text {, higher occupancy }(0.3(95 \% \mathrm{Cl} 0.1 \text { to } 0.5) \mathrm{PP}, \mathrm{p}<0.009) \text {, for-profit status }(4.8(95 \% \mathrm{Cl} \\
0.8 \text { to } 8.8) \mathrm{PP}, \mathrm{p}=0.019) \text {. Comparing states: higher mortality in those with Medicaid (quintile } 5: 6.1(95 \% \mathrm{Cl} 0.0 \text { to } 12.1) \mathrm{PP} \text {, } \\
\mathrm{p}=0.048) \text {. Not significant for other states. More direct care hours per patient day associated with lower COVID-19 deaths. All } \\
\text { states }(-4.8(95 \% \mathrm{Cl}-9.4 \text { to-0.03) PP, } \mathrm{p}<0.04) \text {. }\end{array}$ \\
\hline
\end{tabular}

ADL, activities of daily living; aHR, adjusted HR; aOR, adjusted OR; aRR, adjusted relative risk; LTCF, long-term care facility; PP, percentage points; PPE, personal protective equipment.

prevalence. Similarly, the mortality rate varied widely among studies and prevention measures. However, patterns emerged regarding associations between facility characteristics and the risk of a COVID-19 outbreak and spread. Sepulveda et al report the disproportionately higher risk of contracting COVID-19 for residents of LTCF, calculating a 12-country average mortality rate of 2772 per 100000 LTCF residents compared with 122 per
100000 for community dwelling older persons. ${ }^{56}$ This represented an average 24.2-fold higher rate of death (range 14.2 (Germany) to 73.7 (Canada)). Higher LTCF mortality rates in Canada $(78.4 \%$ compared with the Organisation for Economic Co-operation and Development (OECD) 12 country average of $43.7 \%$ ) are explained by poorer services in care facilities and includes limited staffing and funding. ${ }^{56}$ 
Table 3 Resident-specific outcomes of strategies implemented in nursing homes

\begin{tabular}{|c|c|c|c|c|}
\hline Study & Interventions & Prevalence & Mortality & Other outcomes \\
\hline Arons et $a l^{18}$ & $\begin{array}{l}\text { Mass testing (two point- } \\
\text { prevalence surveys) } \\
\text { PPE }\end{array}$ & $\begin{array}{l}48 / 76(63 \%) \text { across two surveys, } \\
17 / 48 \text { typical symptoms, } 4 / 48 \text { atypical } \\
\text { symptoms, } 3 / 48 \text { asymptomatic, } 24 / 48 \\
\text { presymptomatic } \\
57 / 89 \text { through point-prevalence, clinical } \\
\text { evaluation, post mortem }\end{array}$ & $15 / 57(26 \%)$ & $\begin{array}{l}\text { Common symptoms: fever }(71 \%) \text {, cough } \\
\text { ( } 54 \%) \text {, malaise }(42 \%) \\
\text { Estimated doubling time: } 3.4 \text { days }(95 \% \mathrm{Cl} \\
2.5 \text { to } 5.3 \text { ) }\end{array}$ \\
\hline Blackman et al ${ }^{19}$ & $\begin{array}{l}\text { PPE } \\
\text { Symptom screening } \\
\text { Visitor restrictions }\end{array}$ & $\begin{array}{l}12 \text { positive cases, } 2 \text { awaiting results, } 47 \\
\text { symptomatic residents }\end{array}$ & $\begin{array}{l}3 \text { COVID-19-related } \\
\text { deaths }\end{array}$ & \\
\hline Brown et al ${ }^{42}$ & Facility characteristics & $5218 / 78607$ (6.6\%) & 1452/5218 (27.8\%) & \\
\hline Burton et $a^{38}$ & Facility characteristics & & $\begin{array}{l}403 \text { deaths recorded } \\
\text { in care homes }\end{array}$ & $\begin{array}{l}472 \text { excess deaths in care homes with an } \\
\text { outbreak ( } 399 \text { COVID-19-related) }\end{array}$ \\
\hline Dutey-Magni et a ${ }^{39}$ & Mass testing & 951/9339 (10.2\%) & $526 / 951(55.3 \%)$ & $\begin{array}{l}2075 / 9339(22.2 \%) \text { experienced infection } \\
\text { symptoms }\end{array}$ \\
\hline Eckardt et $\left.a\right|^{21}$ & $\begin{array}{l}\text { Mass testing (three point- } \\
\text { prevalence surveys) } \\
\text { PPE } \\
\text { Symptom screening } \\
\text { Visitor restrictions } \\
\text { Cohorting }\end{array}$ & $\begin{array}{l}\text { Survey 1: 5/105 (4.8\%) } \\
\text { Survey 2: } 4 / 86(4.7 \%) \\
\text { Survey 3: } 1 / 85(1.2 \%)\end{array}$ & & \\
\hline Feaster and $\mathrm{Goh}^{22}$ & Mass testing & $\begin{array}{l}\text { 408/582 }(49.5 \%), 202 / 408(49.5 \%) \\
\text { symptomatic } \\
237 / 332(71.4 \%) \text { female residents } \\
\text { positive, } 121 / 237(51.1 \%) \text { asymptomatic } \\
171 / 250(68.4 \%) \text { male residents } \\
\text { positive, } 81 / 171(47.4 \%) \text { asymptomatic }\end{array}$ & & \\
\hline Hand et $\left.a\right|^{24}$ & $\begin{array}{l}\text { Symptom screening } \\
\text { Hand hygiene, contact } \\
\text { precautions }\end{array}$ & $\begin{array}{l}20 / 130 \text { residents suspected cases, } \\
13 / 20 \text { tested } \\
7 / 13(54 \%) \text { tested positive; } 6 / 7 \text { required } \\
\text { hospitalisation }\end{array}$ & $3 / 7$ (42.9\%) & $\begin{array}{l}\text { No new cases identified after } 18 \text { November } \\
2017\end{array}$ \\
\hline Harris et $a l^{25}$ & Facility characteristics & $\begin{array}{l}41 / 48(85.4 \%) \\
18 / 48 \text { residents hospitalised, } 11 / 18 \\
\text { returned to facility from hospital }\end{array}$ & $6 / 48(12.5 \%)$ & $\begin{array}{l}13 / 48(27.1 \%) \text { of residents received } \\
\text { telemedicine consultations }\end{array}$ \\
\hline Heung et $a l^{47}$ & $\begin{array}{l}\text { Hand hygiene, contact } \\
\text { precautions }\end{array}$ & $\begin{array}{l}2 \text { residents were positive during the } \\
\text { outbreak, } 0 / 67 \text { residents positive for } \\
\text { SARS-CoV antibodies on screening }\end{array}$ & & $2 / 67$ reported symptoms \\
\hline Ho et $a l^{48}$ & $\begin{array}{l}\text { PPE } \\
\text { Cohorting }\end{array}$ & 3 residents positive & $2 / 3(66.7 \%)$ & \\
\hline Hoxha et $\left.a\right|^{49}$ & Mass testing & $\begin{array}{l}5390 / 142100(3.8 \%), 4059 / 5390(75.3 \%) \\
\text { asymptomatic }\end{array}$ & & $\begin{array}{l}\text { Infection odds: Women compared } \\
\text { with men } \mathrm{OR}=1.2(95 \% \mathrm{Cl} 1.1 \text { to } 1.2) \text {; } \\
\text { symptomatic compared with asymptomatic } \\
\mathrm{OR}=8.5(95 \% \mathrm{Cl} 8.0 \text { to } 9.0)\end{array}$ \\
\hline
\end{tabular}

Continued 
Table 3 Continued

\begin{tabular}{|c|c|c|c|c|}
\hline Study & Interventions & Prevalence & Mortality & Other outcomes \\
\hline Kennelly et $a l^{51}$ & $\begin{array}{l}\text { Mass testing } \\
\text { Facility characteristics }\end{array}$ & $\begin{array}{l}710 / 1741(40.1 \%), 54 / 1741(3.1 \%) \\
\text { residents were suspected COVID-19, } \\
193 / 710(27.2 \%) \text { asymptomatic, } \\
396 / 710(55.8 \%) \text { had recovered by the } \\
\text { completion of surveillance period }\end{array}$ & $183 / 710(25.8 \%)$ & $\begin{array}{l}\text { Non-COVID- } 19 \text { mortality rate similar } \\
\text { between outbreak and non-outbreak NHS } \\
(5.1 \% \text { vs } 4 \%, p=0.4)\end{array}$ \\
\hline Kimball et $a l^{26}$ & $\begin{array}{l}\text { Mass testing (three point- } \\
\text { prevalence surveys) } \\
\text { PPE } \\
\text { Symptom screening } \\
\text { Visitor restrictions } \\
\text { Hand hygiene, contact } \\
\text { precautions } \\
\text { Cohorting }\end{array}$ & $\begin{array}{l}23 / 76 \text { (30.3\%), } 10 / 23 \text { symptomatic } \\
\text { (8/10 typical symptoms, } 2 / 10 \text { atypical } \\
\text { symptoms), } 3 / 23 \text { asymptomatic, } 10 / 23 \\
\text { presymptomatic }\end{array}$ & & $\begin{array}{l}\text { Symptoms: fever }(61.5 \%) \text {, malaise }(46.2 \%) \text {, } \\
\text { cough }(38.5) \text {, } \\
\text { Presymptomatic mean interval from testing } \\
\text { to symptom onset was } 3 \text { days }\end{array}$ \\
\hline Klein et $a l^{50}$ & $\begin{array}{l}\text { Mass testing } \\
\text { PPE } \\
\text { Visitor restrictions } \\
\text { Cohorting }\end{array}$ & $39 / 60(65 \%)$ & $8 / 39(20.5 \%)$ & $\begin{array}{l}\text { Symptoms: exhaustion, loss of appetite, } \\
\text { dysphagia, fever, cough, colds, diarrhoea }\end{array}$ \\
\hline Lennon et $a l^{27}$ & Mass testing & $\begin{array}{l}\text { 2654/16966 }(15.5 \%), 1692 / 2654(63.8 \%) \\
\text { asymptomatic, } 699 / 2654(26.3 \%) \\
\text { symptomatic, }(263 / 2654 \text { symptom data } \\
\text { missing) }\end{array}$ & & \\
\hline Louie et $a l^{28}$ & $\begin{array}{l}\text { Mass testing } \\
\text { Symptom screening } \\
\text { Visitor restrictions }\end{array}$ & $\begin{array}{l}214 / 431(49.7 \%) \text { residents and } \\
\text { healthcare workers, } 128 / 214(59.8 \%) \\
\text { symptomatic }(78 / 128 \text { were residents), } \\
86 / 214(40.2 \%) \text { asymptomatic } \\
\text { Additional } 156 \text { asymptomatic residents } \\
\text { subsequently tested: } 63 / 156 \text { COVID-19 } \\
\text { positive }\end{array}$ & $\begin{array}{l}12 / 78(15.4 \%) \\
\text { symptomatic } \\
\text { residents died }\end{array}$ & $\begin{array}{l}22 / 78(28.2 \%) \text { symptomatic residents } \\
\text { hospitalised }\end{array}$ \\
\hline McMichael et $a l^{29}$ & $\begin{array}{l}\text { Mass testing } \\
\text { PPE } \\
\text { Cohorting }\end{array}$ & $101 / 118(58.6 \%)$ & $34 / 101(33.7 \%)$ & $\begin{array}{l}55 / 101 \text { ( } 54.5 \%) \text { hospitalised; ( } 37 / 101 \text { no } \\
\text { data on hospitalisation status) }\end{array}$ \\
\hline $\begin{array}{l}\text { Office for National } \\
\text { Statistics }^{40}\end{array}$ & $\begin{array}{l}\text { Mass testing } \\
\text { Facility characteristics }\end{array}$ & $\begin{array}{l}19.9 \%(95 \% \mathrm{Cl} 18.5 \text { to } 21.3) \text { in homes } \\
\text { with a confirmed outbreak } \\
10.7 \%(95 \% \mathrm{Cl} 10.1 \text { to } 11.3) \text { in all } \\
\text { homes }\end{array}$ & $\begin{array}{l}15606 \text { across all } \\
\text { homes }\end{array}$ & $\begin{array}{l}\text { Odds of resident infection: each additional } \\
\text { infected staff member at a home OR=1.11 } \\
\text { ( } 95 \% \mathrm{Cl} 1.0 \text { to } 1.17) \\
\text { Homes using bank or agency nurses most } \\
\text { or all days OR }=1.58 \text { ( } 95 \% \mathrm{Cl} 1.5 \text { to } 1.65) \\
\text { compared with homes never using these } \\
\text { staff } \\
\text { Homes outside of London had lower } \\
\text { infection chance, except West Midlands } \\
\text { (OR=1.09, } 95 \% \mathrm{Cl} 1.0 \text { to } 1.17) \\
\text { Homes where staff receive sick pay } \\
\text { OR=0.82-0.93 ( } 95 \% \mathrm{Cl} \text { unknown) }\end{array}$ \\
\hline Patel et $a l^{30}$ & $\begin{array}{l}\text { Mass testing } \\
\text { Symptom screening } \\
\text { Visitor restrictions } \\
\text { Cohorting }\end{array}$ & $\begin{array}{l}33 / 118(28.0 \%), 19 / 33(58 \%) \\
\text { symptomatic ( } 8 \text { typical symptoms, } 4 \\
\text { atypical symptoms, } 10 \text { both typical } \\
\text { and atypical symptoms); } 1 / 33(3 \%) \\
\text { presymptomatic, } 13 / 33(39 \%) \\
\text { asymptomatic }\end{array}$ & $\begin{array}{l}10 / 35(28.6 \%)(5 / 10 \\
\text { symptomatic) } \\
30 \text {-day survival=71\% } \\
(95 \% \text { Cl } 52 \text { to } 83)\end{array}$ & $\begin{array}{l}\text { 1/91 negative residents reported } \\
\text { symptoms } \\
35 / 90 \text { negative asymptomatic residents } \\
\text { developed symptoms during } 30 \text {-day } \\
\text { surveillance, } 2 / 35 \text { COVID-19 positive on } \\
\text { re-testing } \\
13 / 35 \text { COVID-19 residents hospitalised }\end{array}$ \\
\hline Roxby et $a l^{33}$ & $\begin{array}{l}\text { Mass testing } \\
\text { Symptom screening } \\
\text { Visitor restrictions } \\
\text { Hand hygiene, contact } \\
\text { precautions } \\
\text { Cohorting }\end{array}$ & $\begin{array}{l}\text { Survey } 1: 3 / 80(3.8 \%), 1 / 3 \text { reported } \\
\text { resolved cough and loose stool during } \\
\text { the preceding } 14 \text { days } \\
\text { Survey } 2: 1 / 77(1.3 \%)\end{array}$ & & $\begin{array}{l}\text { All residents clinically stable } 14 \text { days after } \\
\text { second test } \\
21 \text { days after the test, all cases continued } \\
\text { their usual state of health }\end{array}$ \\
\hline Sacco et $a l^{46}$ & $\begin{array}{l}\text { Mass testing } \\
\text { PPE } \\
\text { Visitor restrictions } \\
\text { Hand hygiene, contact } \\
\text { precautions } \\
\text { Cohorting }\end{array}$ & $\begin{array}{l}41 / 87(47.1 \%) \\
3 / 41 \text { asymptomatic }\end{array}$ & $\begin{array}{l}11 / 41(27 \%) \\
\text { All-cause mortality: } \\
13 \%(95 \% \mathrm{Cl} 7.2 \\
\text { to } 21.2), \text { compared } \\
\text { with } 3 \% \text { for the same } \\
\text { period during the } \\
\text { previous } 5 \text { years }\end{array}$ & $\begin{array}{l}\text { Incidence rate for residents }=1.54 \text { per } 100 \\
\text { person-days } \\
14 / 87(16.1 \%) \text { residents hospitalised }\end{array}$ \\
\hline Sanchez et $\mathrm{al}^{34}$ & $\begin{array}{l}\text { Mass testing (two point- } \\
\text { prevalence surveys) } \\
\text { Cohorting }\end{array}$ & $\begin{array}{l}\text { Survey 1: } 716 / 2218(32.3 \%), 344 / 716 \\
\text { (48\%) symptomatic } \\
\text { Survey 2: } 115 / 637(18.1 \%), 5 / 115(4 \%) \\
\text { symptomatic } \\
\text { Total surveillance period: } 1207 / 2773 \\
(44 \%)\end{array}$ & $287 / 2773(24 \%)$ & 446/2773 (37\%) hospitalised \\
\hline
\end{tabular}




\begin{tabular}{|c|c|c|c|c|}
\hline Study & Interventions & Prevalence & Mortality & Other outcomes \\
\hline Stall et al ${ }^{44}$ & Facility characteristics & $\begin{array}{l}5218 / 75676(6.9 \%) \\
3599 / 5218(69.0 \%) \text { for-profit home } \\
\text { residents } \\
1239 / 5218(23.7 \%) \text { non-profit home } \\
\text { residents } \\
380 / 5218(7.3 \%) \text { municipal home } \\
\text { residents }\end{array}$ & $\begin{array}{l}1452 / 5218(27.8 \%) \\
989 / 3599(27.5 \%) \\
\text { for-profit home } \\
368 / 1239(29.7 \%) \\
\text { non-profit home } \\
95 / 380(25.0 \%) \\
\text { municipal home }\end{array}$ & \\
\hline Stow et $a l^{41}$ & Facility characteristics & & $\begin{array}{l}1532 \text { COVID-19- } \\
\text { related deaths }\end{array}$ & $\begin{array}{l}\text { Highest correlation of increased NEWS } \\
\text { and deaths observed for a } 2 \text {-week lag } \\
(r=0.82, p<0.05) \\
\text { Above baseline measures of high } \\
\text { respiratory rate }(r=0.73, p<0.05 \text { for a } \\
2 \text {-week lag) and low oxygen saturation } \\
(r=0.8, p<0.05 \text { for a } 2 \text {-week lag) appear to } \\
\text { follow the pattern of COVID-19 and non- } \\
\text { COVID-19 deaths }\end{array}$ \\
\hline Telford et $a l^{35}$ & $\begin{array}{l}\text { Mass testing ( } 15 \text { facilities } \\
\text { in response to outbreak, } \\
13 \text { facilities as prevention) }\end{array}$ & $\begin{array}{l}821 / 2868 \text { (28.6\%) } \\
\text { Response group: } 804 / 1703(47.2 \%) \\
\text { Preventive group: } 17 / 1133(1.5 \%) \\
(p<0.0001)\end{array}$ & $\begin{array}{l}\text { Response group: } \\
\text { 131/804 (16.3\%) } \\
\text { Preventive group: } \\
3 / 17(17.6 \%)\end{array}$ & $\begin{array}{l}\text { Response group: } 171 / 804(21.3 \%) \\
\text { residents hospitalised } \\
\text { Preventive group: } 5 / 17 \text { (29.4\%) residents } \\
\text { hospitalised }\end{array}$ \\
\hline
\end{tabular}

IRR, incidence risk ratio; LTCF, long-term care facility; NEWS, National Early Warning Score; PPE, personal protective equipment.

Evidence identified the facility size/number of beds was significantly associated with the probability of having a COVID-19 case, and the resulting size of an outbreak. For example, in a sample of 30 US nursing homes, the probability of having a COVID-19 case was increased in medium and large facilities compared with small facilities, ${ }^{17}$ while in 121 UK homes reporting an outbreak, facilities with $\geq 70$ beds had $80 \%$ greater infection rates than facilities with $<35$ beds. ${ }^{39}$ A sample of 623 Canadian nursing homes demonstrated facilities with a high crowding index had more infections and deaths than those with a low crowding index. Simulations conducted suggested nearly $20 \%$ of infections and deaths may have been averted by converting all four-bed rooms into two-bed rooms. ${ }^{42}$ Similarly, facilities with a greater number of employees, staff who work in multiple facilities and an increased number of infected staff, were also more likely to experience a COVID-19 outbreak. ${ }^{37} 40$ However, facilities where staff receive sick leave were shown to be less likely to have positive cases. ${ }^{40}$ Reduced availability of PPE predicted the spread and increase in case number in facilities, ${ }^{37}$ while for-profit status of facilities was commonly identified as increasing the odds of case outbreaks relative to non-profit status. ${ }^{1732} 364344$

Rapid development of COVID-19 vaccines was recognised in early March $2020 .^{57}$ Lurie et alnote previous success in the development of H1N1 vaccination, and similarly the challenges for SARS, Ebola and Zika vaccines. ${ }^{57}$ The speed of developments is acknowledged, and Public Health England report that at the end of February 2021 up to 5900 deaths were averted in people aged 80 years and older, with over 200 deaths prevented in those aged 7-79 years. ${ }^{58}$ Montano advises that an accelerated pace of vaccine developments may not lead to total eradication of the virus, citing smallpox as the only virus that has been eliminated worldwide.$^{59}$ Given this, the transmission reduction measures highlighted in the present review are of crucial importance for the continued management of COVID-19 in LTCF.

\section{Quality review}

The quality of evidence in this review is technically low, primarily reported from observational studies, expert opinion, reporting of outbreaks and describing the process and management (online supplemental table 2). Factors associated with lower quality of evidence include the reliance on self-reporting of symptoms, recall bias, use of datasets which may be incomplete and use of convenience sampling. However, confirmation of COVID-19 in the majority of studies was via laboratory testing. We did not remove any study following our review of quality and the evidence is consistent with real-time reporting of data to learn from outbreaks. Papers included from MEDRXIV pre publishing repository are acknowledged; however, as papers were subsequently published in peer review journals we reviewed accordingly. The Institute of Medicine $^{60}$ advocates for early detection of epidemics, effective communication to the public and promotion of research and development for strategic planning.

\section{Limitations in the review process}

A key strength of this review is that it addresses a knowledge gap and has collated evidence from a broad methodological base to report the measures to reduce transmission of COVID-19 in LTCF and reports characteristics of facilities.

Due to the heterogeneity of included studies, metaanalysis was not performed, while the descriptive nature of studies prevents identification of a causative relationship between measures and outcomes. We acknowledge that while a summary of facility characteristics and COVID-19 outcomes are presented, insufficient evidence is available to statistically evaluate and summarise the relationship between individual measures to prevent COVID-19 transmission and thus further research studies are required to elucidate this. Despite this, the systematic approach 
Table 4 Staff-specific outcomes of strategies to reduce transmission

\begin{tabular}{|c|c|c|c|c|}
\hline Study & Interventions & Prevalence & Mortality & Other outcomes \\
\hline Arons et $\mathrm{al}^{18}$ & $\begin{array}{l}\text { Mass testing } \\
\text { PPE }\end{array}$ & $\begin{array}{l}26 / 51(51.0 \%) \\
17 / 26(65 \%) \text { were nursing staff, } 9 / 26(35 \%) \\
\text { had roles that provided care/therapies } \\
\text { across multiple units }\end{array}$ & & 0/26 hospitalised \\
\hline Blackman et a $\left.\right|^{19}$ & $\begin{array}{l}\text { PPE } \\
\text { Symptom screening } \\
\text { Visitor restrictions }\end{array}$ & & & $\begin{array}{l}26 \text { staff members absent from work due to } \\
\text { sickness }\end{array}$ \\
\hline $\begin{array}{l}\text { Borras-Bermejo } \\
\text { et }\left.a\right|^{54}\end{array}$ & $\begin{array}{l}\text { Mass testing } \\
\text { Visitor restrictions }\end{array}$ & $\begin{array}{l}403 / 2655(15.2 \%), 144 / 403(35.7 \%) \\
\text { asymptomatic }\end{array}$ & & $\begin{array}{l}1772 / 2665(66.7 \%) \text { staff reported fever or } \\
\text { respiratory symptoms in the preceding } 14 \text { days }\end{array}$ \\
\hline Dora et $a l^{20}$ & $\begin{array}{l}\text { Mass testing (three point- } \\
\text { prevalence surveys) } \\
\text { Symptom screening } \\
\text { Visitor restrictions } \\
\text { Hand hygiene, contact } \\
\text { precautions } \\
\text { Cohorting }\end{array}$ & $\begin{array}{l}8 / 136(6 \%) \\
4 / 8(50 \%) \text { asymptomatic } \\
3 / 8 \text { nursing staff } \\
5 / 8 \text { licensed vocational nurses }\end{array}$ & & \\
\hline Dutey-Magni et a/ ${ }^{39}$ & Mass testing & $585 / 11604(5.0 \%)$ & & $1892 / 11604$ (16.3\%) reported symptoms \\
\hline Eckardt et $a l^{21}$ & $\begin{array}{l}\text { Mass testing (three point- } \\
\text { prevalence surveys) } \\
\text { PPE } \\
\text { Symptom screening } \\
\text { Visitor restrictions } \\
\text { Cohorting }\end{array}$ & $\begin{array}{l}\text { Survey } 1: 10 / 176(5.7 \%), 10 / 10(100 \%) \\
\text { asymptomatic } \\
\text { Survey } 2: 5 / 175(2.9 \%), 5 / 5(100 \%) \\
\text { asymptomatic } \\
\text { Survey } 3: 1 / 173(0.6 \%), 1 / 1(100 \%) \\
\text { asymptomatic }\end{array}$ & & \\
\hline Feaster and $\mathrm{Goh}^{22}$ & Mass testing & $\begin{array}{l}223 / 356(62.6 \%), 55 / 223(24.7 \%) \\
\text { asymptomatic }\end{array}$ & & $\begin{array}{l}\text { Infection prevalence higher in staff with direct } \\
\text { resident contact }(150 / 219,68.5 \%) \text { compared } \\
\text { with staff with no direct resident contact }(25 / 52 \text {, } \\
48.1 \%)\end{array}$ \\
\hline Fisman et $a l^{43}$ & Facility characteristics & & & $\begin{array}{l}\text { Infection among LTCF staff was associated } \\
\text { with death among residents with a } 6 \text {-day } \\
\text { lag (adjusted IRR for death per infected staff } \\
\text { member, } 1.17 ; 95 \% \mathrm{Cl} 1.11 \text { to } 1.26 \text { ) and a } 2 \text { - } \\
\text { day lag (relative increase in risk of death per } \\
\text { staff member with infection, } 1.20 ; 95 \% \mathrm{Cl} 1.14 \\
\text { to } 1.26 \text { ) }\end{array}$ \\
\hline Graham et $a l^{23}$ & $\begin{array}{l}\text { Mass testing (two point- } \\
\text { prevalence surveys) } \\
\text { Cohorting }\end{array}$ & $\begin{array}{l}3 / 70(4.3 \%) \\
3 / 3(100 \%) \text { asymptomatic }\end{array}$ & & $\begin{array}{l}\text { Staff absence due to sickness/self-isolation } \\
\text { between } 1 \text { March and } 1 \text { May elevated relative } \\
\text { to background level ( } 215.9 \% \text { increase, } 95 \% \mathrm{Cl} \\
80 \text { to } 352)\end{array}$ \\
\hline Guery et $a l^{45}$ & Mass testing & $\begin{array}{l}3 / 136(2.2 \%) \\
1 / 3(33.3 \%) \text { asymptomatic } \\
1 / 3(33.3 \%) \text { presymptomatic } \\
1 / 3(33.3 \%) \text { symptomatic }\end{array}$ & & \\
\hline Harris et $a l^{25}$ & Facility characteristics & $\begin{array}{l}7 \text { staff COVID-19 positive prior to } \\
\text { intervention } \\
0 \text { further staff positive after intervention } \\
\text { implemented }\end{array}$ & & \\
\hline Heung et $a l^{47}$ & $\begin{array}{l}\text { Hand hygiene, contact } \\
\text { precautions }\end{array}$ & $\begin{array}{l}1 \text { staff member SARS-CoV positive during } \\
\text { outbreak (a domestic worker) } \\
\text { 0/26 staff positive for SARS-CoV } \\
\text { antibodies }\end{array}$ & & \\
\hline Ho et $a l^{48}$ & $\begin{array}{l}\text { PPE } \\
\text { Cohorting }\end{array}$ & 1 staff member SARS positive & $1 / 1(100 \%)$ & \\
\hline Hoxha et $a l^{49}$ & Mass testing & $\begin{array}{l}2953 / 138327(2.1 \%) \\
2185 / 2953(74.0 \%) \text { asymptomatic }\end{array}$ & & \\
\hline Kennelly et $a l^{51}$ & $\begin{array}{l}\text { Mass testing } \\
\text { Facility characteristics }\end{array}$ & $\begin{array}{l}675 \text { staff COVID-19 positive } \\
159 / 675(23.6 \%) \text { asymptomatic }\end{array}$ & & $\begin{array}{l}\text { Proportion of symptomatic staff correlated with } \\
\text { number of residents with confirmed/suspected } \\
\text { COVID-19, } \rho=0.81(p<0.001)\end{array}$ \\
\hline Lennon et $a l^{27}$ & Mass testing & $\begin{array}{l}624 / 15514(4.1 \%) \\
487 / 624(78.0 \%) \text { asymptomatic } \\
40 / 624(6.4 \%) \text { symptomatic }\end{array}$ & & \\
\hline Louie et $a l^{28}$ & $\begin{array}{l}\text { Mass testing } \\
\text { Symptom screening } \\
\text { Visitor restrictions }\end{array}$ & $\begin{array}{l}214 / 431(49.7 \%) \text { residents and staff } \\
\text { COVID-19 positive } \\
86 / 214 \text { asymptomatic } \\
128 / 214 \text { symptomatic }(50 / 128 \text { were } \\
\text { healthcare workers) } \\
\text { Additional asymptomatic staff testing: } \\
23 / 147(15.6 \%) \text { staff COVID-19 positive }\end{array}$ & & $\begin{array}{l}0 / 50 \text { symptomatic healthcare workers } \\
\text { hospitalised }\end{array}$ \\
\hline
\end{tabular}


Table 4 Continued

\begin{tabular}{|c|c|c|c|c|}
\hline Study & Interventions & Prevalence & Mortality & Other outcomes \\
\hline McMichael et $a l^{29}$ & $\begin{array}{l}\text { Mass testing } \\
\text { PPE } \\
\text { Cohorting }\end{array}$ & 50 staff COVID-19 positive & $0 / 50(0 \%)$ & $\begin{array}{l}3 / 50(6 \%) \text { hospitalised } \\
\text { Staff roles for confirmed cases: therapists, } \\
\text { nurses, nurse assistants, health information } \\
\text { manager, physician, case manager }\end{array}$ \\
\hline $\begin{array}{l}\text { Office for National } \\
\text { Statistics }^{40}\end{array}$ & $\begin{array}{l}\text { Mass testing } \\
\text { Facility characteristics }\end{array}$ & $\begin{array}{l}\text { Estimated } 6.9 \% \text { ( } 95 \% \text { CI } 5.9 \% \text { to } 7.9 \%) \\
\text { staff COVID- } 19 \text { positive across homes that } \\
\text { reported an outbreak }\end{array}$ & & $\begin{array}{l}\text { Odds of staff infection: for each additional } \\
\text { infected resident, staff infection OR=1.04 (95\% } \\
\mathrm{Cl} 1.04 \text { to } 1.04) \\
\text { Care homes using bank or agency staff most } \\
\text { or every day OR=1.88 ( } 95 \% \mathrm{Cl} 1.77 \text { to } 2.0) \\
\text { compared with homes not using these staff } \\
\text { Homes where staff work in other homes most } \\
\text { or every day OR=2.4 ( } 95 \% \mathrm{Cl} 1.92 \text { to } 3.0) \\
\text { compared with homes where staff never work } \\
\text { elsewhere } \\
\text { Staff at homes outside London had higher odds } \\
\text { of COVID-19 infection }\end{array}$ \\
\hline
\end{tabular}

\begin{tabular}{|c|c|c|c|c|}
\hline Patel et $a l^{30}$ & $\begin{array}{l}\text { Mass testing } \\
\text { Symptom screening } \\
\text { Visitor restrictions } \\
\text { Cohorting }\end{array}$ & $\begin{array}{l}19 / 42(45.2 \%) \\
11 / 19 \text { symptomatic }(57.9 \%) \\
8 / 19(42.1 \%) \text { asymptomatic }\end{array}$ & & \\
\hline Quicke et $\left.a\right|^{31}$ & $\begin{array}{l}\text { Mass testing (five point- } \\
\text { prevalence surveys) }\end{array}$ & $\begin{array}{l}\text { Site A: all staff uninfected } \\
\text { Site B: low prevalence in week } 1 \text {, weeks } \\
2-5 \text { no infections detected, week } 6 \\
\text { increase in cases } \\
\text { Site C: initial infection prevalence was } \\
\text { lower ( } 6.9 \%) \text {, and the incidence declined } \\
\text { to zero by week } 3 \\
\text { Site D: } 22.5 \% \text { of workers at site D had } \\
\text { prevalent infections at the start of the } \\
\text { study and incidence was high initially ( } 12.2 \\
\text { per } 100 \text { workers per week), declining over } \\
\text { time } \\
\text { Site E: low prevalence in week } 1 \text { saw an } \\
\text { increase in cases in subsequent weeks }\end{array}$ & & \\
\hline Roxby et $a l^{33}$ & $\begin{array}{l}\text { Mass testing } \\
\text { Symptom screening } \\
\text { Visitor restrictions } \\
\text { Hand hygiene, contact } \\
\text { precautions } \\
\text { Cohorting }\end{array}$ & $\begin{array}{l}2 / 62(3.2 \%)(1 \text { worked in dining facilities, } 1 \\
\text { was a health aide) } \\
2 / 2(100 \%) \text { symptomatic }\end{array}$ & & \\
\hline Sacco et $a l^{46}$ & $\begin{array}{l}\text { Mass testing } \\
\text { PPE } \\
\text { Visitor restrictions } \\
\text { Hand hygiene, contact } \\
\text { precautions } \\
\text { Cohorting }\end{array}$ & $\begin{array}{l}22 \text { staff COVID-19 positive } \\
9 / 22(40.1 \%) \text { asymptomatic }\end{array}$ & $0 / 22(0 \%)$ & $\begin{array}{l}\text { Staff incidence: care givers }=0.48 / 100 \text { person- } \\
\text { days } \\
\text { Non-care givers with resident contact }=0.36 / 100 \\
\text { person-days } \\
\text { Non-care givers with no resident } \\
\text { contact }=0.04 / 100 \text { person-days }\end{array}$ \\
\hline Stall et $a l^{44}$ & Facility characteristics & & & $\begin{array}{l}\text { Outbreak involving staff and residents' for-profit } \\
\text { homes } 59 / 360 \text { and staff only } 44 / 360 \\
\text { Non-profit homes staff only } 18 / 162 \text {. } \\
\text { Municipal homes=outbreak staff only } 16 / 101\end{array}$ \\
\hline Telford et $a l^{35}$ & $\begin{array}{l}\text { Mass testing ( } 15 \text { facilities } \\
\text { in response to outbreak, } 13 \\
\text { facilities as prevention) }\end{array}$ & $\begin{array}{l}264 / 2803 \text { (9.4\%) } \\
\text { Response group: } 249 / 264(94.3 \%) \\
\text { Preventive group: } 15 / 264(5.7 \%)(d) \\
\text { Prevalence: response group } 12.8 \% \text { vs } \\
\text { preventive group } 1.7 \%, p<0.0001\end{array}$ & $\begin{array}{l}1 / 264(0.4 \%) \\
\text { Response } \\
\text { group: } 0 / 249 \\
\text { (0\%) } \\
\text { Preventive } \\
\text { group: } 1 / 15 \\
(6.7 \%)\end{array}$ & $\begin{array}{l}\text { 16/264 (6.1\%) hospitalised } \\
\text { Response group: } 15 / 249(6.0 \%) \text { hospitalised } \\
\text { Preventive group: } 1 / 15(6.7 \%) \text { hospitalised } \\
\text { 15/249 }\end{array}$ \\
\hline
\end{tabular}

IRR, incidence risk ratio; LTCF, long-term care facility.

to this review has identified the scope of interventions implemented in LTCF to reduce COVID-19 transmission.

Publication bias was minimised with inclusion of prepublished evidence, follow-up contacts with authors for early reporting and through the inclusion of observational study designs. Most studies reported are in English, we translated papers from German and Spanish as part of the assessment and review. Outbreak reports include convenience samples or smaller cohorts of residents in LTCF with limited data reported in brief reports and letters. However, real-time reporting of outbreaks provides immediate evidence and shared understanding advocated by the Institute of Medicine. ${ }^{60}$

Evidence in this review builds on publications from Salcher-Konrad et $a l,{ }^{61}$ a report from $\mathrm{WHO}^{62}$ and an Irish Expert Panel review ${ }^{55}$ furthermore, data on the role of facilities in the transmission of COVID-19 are presented. 
Table 5 Visitor-specific outcomes following the implementation of strategies

\begin{tabular}{|c|c|c|c|c|}
\hline Study & Interventions & Prevalence & Mortality & Other outcomes \\
\hline Ho et $a l^{48}$ & $\begin{array}{l}\text { PPE } \\
\text { Cohorting }\end{array}$ & $\begin{array}{l}3 \text { visitors SARS } \\
\text { positive }\end{array}$ & 0/3 (0\%) & \\
\hline
\end{tabular}

PPE, personal protective equipment.

\section{CONCLUSION}

This novel, rapid review summarises the evidence base to date identifying specific factors for consideration as part of preparedness plans to reduce transmission of COVID-19 outbreaks in LTCF. Future research should incorporate methodologically robust study designs with longer follow-up to assess the impact on reducing transmission.

\section{Twitter Kate Frazer @katef224 and Lachlan Mitchell @doclach5195}

Contributors CCK, KF and LM designed the study; KF and DS developed the search strategy; DS conducted the literature search; KF and LM screened titles and full texts to select studies, and extracted data; LM, EL, KF and CCK conducted quality ratings; KF, LM, DS, EL, EC, CCK interpreted and synthesised data; KF, LM, $D S, E L, E C, C C K$ were involved in writing. All authors have approved the final version of the manuscript. CCK acts as the guarantor for this work.

Funding The authors have not declared a specific grant for this research from any funding agency in the public, commercial or not-for-profit sectors.

Competing interests CCK was a member of an expert panel investigating COVID-19 in nursing homes in Ireland.

Patient consent for publication Not applicable.

Provenance and peer review Not commissioned; externally peer reviewed.

Data availability statement № data are available.

Supplemental material This content has been supplied by the author(s). It has not been vetted by BMJ Publishing Group Limited (BMJ) and may not have been peer-reviewed. Any opinions or recommendations discussed are solely those of the author(s) and are not endorsed by BMJ. BMJ disclaims all liability and responsibility arising from any reliance placed on the content. Where the content includes any translated material, BMJ does not warrant the accuracy and reliability of the translations (including but not limited to local regulations, clinical guidelines, terminology, drug names and drug dosages), and is not responsible for any error and/or omissions arising from translation and adaptation or otherwise.

Open access This is an open access article distributed in accordance with the Creative Commons Attribution Non Commercial (CC BY-NC 4.0) license, which permits others to distribute, remix, adapt, build upon this work non-commercially, and license their derivative works on different terms, provided the original work is properly cited, appropriate credit is given, any changes made indicated, and the use is non-commercial. See: http://creativecommons.org/licenses/by-nc/4.0/.

\section{ORCID iDs}

Kate Frazer http://orcid.org/0000-0002-6703-266X

Lachlan Mitchell http://orcid.org/0000-0003-1316-3688

\section{REFERENCES}

1 European Centre for Disease Prevention and Control (ECDC). Timeline of ECDC's response to COVID-19, 2020. Available: https:// www.ecdc.europa.eu/en/covid-19/timeline-ecdc-response [Accessed 04 Oct 2020].

2 World Health Organization. Coronavirus disease 2019 (COVID-19) situation report - 94, 2020.
3 Nussbaumer-Streit B, Mayr V, Dobrescu Al, et al. Quarantine alone or in combination with other public health measures to control COVID-19: a rapid review. Cochrane Database Syst Rev 2020;4:Cd013574.

4 European Centre for Disease Prevention and Control (ECDC). Risk assessment: outbreak of acute respiratory syndrome associated with a novel coronavirus, Wuhan, China. Stockholm: ECDC, 2020. https://www.ecdc.europa.eu/en/publications-data/rapid-riskassessment-cluster-pneumonia-cases-caused-novel-coronaviruswuhan2020

5 World Health Organization. Statement on the second meeting of the International health regulations (2005) emergency Committee regarding the outbreak of novel coronavirus (2019-nCoV. Geneva: WHO, 2020. https://www.who.int/news-room/detail/30-01-2020statement-on-the-second-meeting-of-the-international-healthregulations-(2005)-emergency-committee-regarding-the-outbreak-ofnovel-coronavirus-(2019-ncov)

6 Meng X, Deng Y, Dai Z, et al. COVID-19 and anosmia: a review based on up-to-date knowledge. Am J Otolaryngol 2020;41:102581-81.

7 European Centre for Disease Prevention and Control (ECDC). COVID-19 situation update worldwide, as of week 12, 2021. Available: https://www.ecdc.europa.eu/en/geographical-distribution2019-ncov-cases [Accessed 08 Apr 2021].

8 European Centre for Disease Prevention and Control (ECDC). Surveillance of COVID-19 at longterm care facilities in the EU/EEA. technical report 2020.

9 ECDC Public Health Emergency Team, Danis K, Fonteneau L, et al. High impact of COVID-19 in long-term care facilities, suggestion for monitoring in the EU/EEA, may 2020. Euro Surveill 2020;25:2000956.

10 Mueller AL, McNamara MS, Sinclair DA. Why does COVID-19 disproportionately affect older people? Aging 2020;12:9959-81.

11 United Nations. Policy brief: the impact of COVID-19 on older persons, 2020.

12 World Health Organization. Policy brief: the impact of COVID-19 on older persons, 2020.

13 Frazer K, Mitchell L, Stokes D. Systematic review of measures to protect older people in long term care facilities from COVID 19. Prospero: International prospective register of systematic reviews, 2020.

14 Moher D, Liberati A, Tetzlaff J, et al. Preferred reporting items for systematic reviews and meta-analyses: the PRISMA statement. PLoS Med 2009;6:e1000097.

15 Hong QN, Fàbregues S, Bartlett G, et al. The mixed methods appraisal tool (MMAT) version 2018 for information professionals and researchers. Education for Information 2018;34:285-91.

16 Campbell M, McKenzie JE, Sowden A, et al. Synthesis without meta-analysis (swim) in systematic reviews: reporting guideline. BMJ 2020;368:16890.

17 Abrams HR, Loomer L, Gandhi A, et al. Characteristics of U.S. nursing homes with COVID-19 cases. J Am Geriatr Soc 2020;68:1653-6.

18 Arons MM, Hatfield KM, Reddy SC, et al. Presymptomatic SARSCoV-2 infections and transmission in a skilled nursing facility. $N$ Engl J Med 2020;382:2081-90.

19 Blackman C, Farber S, Feifer RA, et al. An illustration of SARS-CoV-2 dissemination within a skilled nursing facility using heat maps. J Am Geriatr Soc 2020;68:2174-8.

20 Dora AV, Winnett A, Jatt LP, et al. Universal and Serial Laboratory Testing for SARS-CoV-2 at a Long-Term Care Skilled Nursing Facility for Veterans - Los Angeles, California, 2020. MMWR Morb Mortal Wkly Rep 2020;69:651-5.

21 Eckardt P, Guran R, Hennemyre J, et al. Hospital affiliated long term care facility COVID-19 containment strategy by using prevalence 
testing and infection control best practices. Am J Infect Control 2020;48:1552-5.

22 Feaster M, Goh Y-Y. High proportion of asymptomatic SARS-CoV-2 infections in 9 long-term care facilities, Pasadena, California, USA April 2020. Emerg Infect Dis 2020;26:2416-9.

23 Graham NSN, Junghans C, Downes R, et al. SARS-CoV-2 infection, clinical features and outcome of COVID-19 in United Kingdom nursing homes. J Infect 2020;81:411-9.

24 Hand J, Rose EB, Salinas A, et al. Severe respiratory illness outbreak associated with human coronavirus NL63 in a long-term care facility. Emerg Infect Dis 2018;24:1964-6.

25 Harris DA, Archbald-Pannone L, Kaur J, et al. Rapid TelehealthCentered response to COVID-19 outbreaks in Postacute and longterm care facilities. Telemed J E Health 2021;27:102-6.

26 Kimball A, Hatfield KM, Arons M, et al. Asymptomatic and Presymptomatic SARS-CoV-2 Infections in Residents of a Long-Term Care Skilled Nursing Facility - King County, Washington, March 2020. MMWR Morb Mortal Wkly Rep 2020;69:377-81.

27 Lennon NJ, Bhattacharyya RP, Mina MJ. Comparison of viral levels in individuals with or without symptoms at time of COVID-19 testing among 32,480 residents and staff of nursing homes and assisted living facilities in Massachusetts. medRxiv2020:2020.07.20.20157792.

28 Louie JK, Scott HM, DuBois A, et al. Lessons from Mass-Testing for coronavirus disease 2019 in long-term care facilities for the elderly in San Francisco. Clinical Infectious Diseases 2021;72:2018-20.

29 McMichael TM, Currie DW, Clark S, et al. Epidemiology of covid-19 in a long-term care facility in King County, Washington. N Engl J Med 2020;382:2005-11.

30 Patel MC, Chaisson LH, Borgetti S, et al. Asymptomatic SARSCoV-2 infection and COVID-19 mortality during an outbreak investigation in a skilled nursing facility. Clinical Infectious Diseases 2020;71:2920-6.

31 Quicke K, Gallichote E, Sexton N. Longitudinal surveillance for SARS-CoV-2 RNA among asymptomatic staff in five Colorado skilled nursing facilities: epidemiologic, virologic and sequence analysis. medRxiv2020:2020.06.08.20125989.

32 Quigley DD, Dick A, Agarwal M, et al. COVID-19 preparedness in nursing homes in the midst of the pandemic. J Am Geriatr Soc 2020;68:1164-6.

33 Roxby AC, Greninger AL, Hatfield KM, et al. Outbreak investigation of COVID-19 among residents and staff of an independent and assisted living community for older adults in Seattle, Washington. JAMA Intern Med 2020;180:1101-5

34 Sanchez GV, Biedron C, Fink LR, et al. Initial and Repeated Point Prevalence Surveys to Inform SARS-CoV-2 Infection Prevention in 26 Skilled Nursing Facilities - Detroit, Michigan, March-May 2020. MMWR Morb Mortal Wkly Rep 2020;69:882-6.

35 Telford CT, Onwubiko U, Holland D, et al. Mass screening for SARS-CoV-2 infection among residents and staff in Twenty-eight long-term care facilities in Fulton County, Georgia. medRxiv 2020:2020.07.01.20144162.

36 Unruh MA, Yun $\mathrm{H}$, Zhang $\mathrm{Y}$, et al. Nursing home characteristics associated with COVID-19 deaths in Connecticut, new Jersey, and new York. J Am Med Dir Assoc 2020;21:1001-3.

37 Brainard J, Rushton S, Winters T, et al. Introduction to and spread of COVID-19-like illness in care homes in Norfolk, UK. J Public Health 2021;43:228-35

38 Burton JK, Bayne G, Evans C, et al. Evolution and effects of COVID-19 outbreaks in care homes: a population analysis in 189 care homes in one geographical region of the UK. Lancet Healthy Longev 2020;1:e21-31.

39 Dutey-Magni PF, Williams H, Jhass A. Covid-19 infection and attributable mortality in UK long term care facilities: cohort study using active surveillance and electronic records (March-June 2020). Age and Ageing 2021:afab060.

40 Office for National Statistics. Impact of coronavirus in care homes in England: 26 may to 19 June 2020. they Vivaldi study, 2020.
41 Stow D, Barker RO, Matthews FE. National early warning scores (news / NEWS2) and COVID-19 deaths in care homes: a longitudinal ecological study. medRxiv2020:2020.06.15.20131516.

42 Brown KA, Jones A, Daneman N, et al. Association between nursing home crowding and COVID-19 infection and mortality in Ontario, Canada. JAMA Intern Med 2021;181:229-36.

43 Fisman DN, Bogoch I, Lapointe-Shaw L, et al. Risk factors associated with mortality among residents with coronavirus disease 2019 (COVID-19) in long-term care facilities in Ontario, Canada. JAMA Netw Open 2020;3:e2015957-e57.

44 Stall NM, Jones A, Brown KA, et al. For-Profit long-term care homes and the risk of COVID-19 outbreaks and resident deaths. CMAJ 2020;192:E946-55.

45 Guery R, Delaye C, Brule N, et al. Limited effectiveness of systematic screening by nasopharyngeal RT-PCR of Medicalized nursing home staff after a first case of COVID-19 in a resident. Med Mal Infect 2020;50:748-50.

46 Sacco G, Foucault G, Briere O, et al. COVID-19 in seniors: findings and lessons from mass screening in a nursing home. Maturitas 2020;141:46-52.

47 Heung LCL, Li T, Mak SK. Prevalence of subclinical infection and transmission of severe acute respiratory syndrome (SARS) in a residential care home for the elderly. Hong Kong Med $J$ 2006;12:201-7.

48 Ho WW, Hui E, Kwok TC, et al. An outbreak of severe acute respiratory syndrome in a nursing home. J Am Geriatr Soc 2003;51:1504-5

49 Hoxha A, Wyndham-Thomas C, Klamer S, et al. Asymptomatic SARS-CoV-2 infection in Belgian long-term care facilities. Lancet Infect Dis 2021;21:e67.

50 Klein A, Edler C, Fitzek A, et al. Der erste COVID-19-Hotspot in einer Hamburger Senioreneinrichtung. Rechtsmedizin 2020;30:325-31.

51 Kennelly SP, Dyer AH, Noonan C, et al. Asymptomatic carriage rates and case fatality of SARS-CoV-2 infection in residents and staff in Irish nursing homes. Age Ageing 2021;50:49-54.

52 Iritani O, Okuno T, Hama D, et al. Clusters of COVID-19 in long-term care hospitals and facilities in Japan from 16 January to 9 may 2020. Geriatr Gerontol Int 2020;20:715-9.

$53 \mathrm{Kim} \mathrm{T}$. Improving preparedness for and response to coronavirus disease 19 (COVID-19) in long-term care hospitals in Korea. Infect Chemother 2020;52:133.

54 Borras-Bermejo B, Martínez-Gómez X, San Miguel MG, et al. Asymptomatic SARS-CoV-2 infection in nursing homes, Barcelona, Spain, April 2020. Emerg Infect Dis 2020;26:2281-3.

55 Kelleher CC, Doherty B, Donnelly P. COVID-19 nursing homes expert panel. examination of measures to 2021. Report to the Minister for Health 2020.

56 Sepulveda ER, Stall NM, Sinha SK. A comparison of COVID-19 mortality rates among long-term care residents in 12 OECD countries. J Am Med Dir Assoc 2020;21:1572-4.

57 Lurie N, Saville M, Hatchett R, et al. Developing Covid-19 vaccines at pandemic speed. N Engl J Med 2020;382:1969-73.

58 Public Health England. Impact of COVID-19 vaccines on mortality in England December 2020 to February 2021. London, 2021.

59 Montano M. Pressing questions and challenges in the HIV1 and SARS-CoV-2 Syndemic. AIDS Res Hum Retroviruses 2021;37:589-600.

60 Institute of Medicine (IOM). Learning from SARS: Preparing for the Next Disease Outbreak: Workshop Summary. In: Knobler S, Mahmoud A, Lemon S, eds. Learning from SARS: preparing for the next disease outbreak: workshop summary. Washington (DC: National Academies Press (US), Copyright (C) 2004, National Academy of Sciences, 2004

61 Salcher-Konrad M, Jhass A, Naci H. COVID-19 related mortality and spread of disease in long-term care: a living systematic review of emerging evidence. medRxiv2020:2020.06.09.20125237.

62 World Health Organization. Preventing and managing COVID-19 across long-term care services: policy brief. Geneva, 2020. 